\title{
PENERAPAN METODE MULTI FACTOR EVALUATION PROCESS DALAM REKOMENDASI MASKAPAI PENERBANGAN
}

\author{
Cahyani Budihartanti ${ }^{1}$, Yumi Novita Dewi ${ }^{2}$, Indah \\ Purnamasari $^{3}$ \\ Program Studi Sistem Informasi $i^{1,2,3}$ \\ Fakultas Teknologi Informasi ${ }^{1,2,3}$ \\ Universitas Nusa Mandiri ${ }^{1,2,2}$ \\ cahyani.cbh@nusamandiri.ac.id ${ }^{1}$, yumi.ymd@nusamandiri.ac.id ${ }^{2}$, \\ indah.ihi@nusamandiri.ac.id ${ }^{3}$
}

\begin{abstract}
Received: May 24, 2021. Revised: May 28, 2021. Accepted: June 02, 2021. Published: June 20, 2021. Issue Period: Vol.5 No.1 (2021), Pp.16-25
\end{abstract}

\begin{abstract}
Abstrak: Moda transportasi udara merupakan pilihan tepat ketika seseorang akan bepergian jauh dan membutuhkan waktu yang relative lebih cepat untuk sampai ketujuan. Ada beberapa faktor yang perlu diperhatikan oleh penumpang dalam memilih moda transportasi antara lain ketepatan waktu, kemanan, kecepatan, biaya dan tarif serta kenyamanan pelayanan yang diberikan. Pada penelitian ini ada 5 (lima) faktor terpenting yang akan digunakan, dalam merekomendasikan maskapai penerbangan dengan menerapkan metode Multi Factor Evaluation Process (MFEP) yaitu : fasilitas, pelayanan dan kenyamanan, ketepatan waktu penerbangan, Refund, Riwayat Kecelakaan dan yang terakhir yaitu harga. Dengan memberikan pembobotan pada setiap faktor penting yang digunakan, maka Garuda Indonesia merupakan maskapai penerbangan yang akan direkomendasi dengan nilai tertinggi yaitu 4.264.
\end{abstract}

Kata kunci: Rekomendasi Maskapai, Multi Factor Evaluation Process, Pengambilan Keputusan

\begin{abstract}
Air transportation mode is the right choice when someone is going to travel far and requires relatively faster time to get to the destination. There are several factors that need to be considered by passengers in choosing a mode of transportation, including timeliness, safety, speed, cost and tariff as well as the convenience of service. given. In this study, there are 5 (five) most important factors that will be used, in recommending airlines by applying the Multi Factor Evaluation Process (MFEP) method, namely: facilities, service and comfort, flight timeliness, refunds, accident history and finally price. By giving weight to each important factor used, Garuda Indonesia is the airline that will be recommended with the highest score, namely 4,264.
\end{abstract}

Keywords: Airline Recommendation, Multi Factor Evaluation Process, Decision Making

\section{PENDAHULUAN}

Pemilihan moda transportasi merupakan prioritas seseorang akan melakukan perjalanan dalam setiap aktifitas, banyak hal yang perlu diperhatikan oleh penumpang dalam memilih moda transportasi antara lain ketepatan waktu, kemanan, kecepatan, biaya dan tarif serta kenyamanan pelayanan yang diberikan. Saat ini moda transportasi udara menjadi pilihan utama karena jenis transportasi ini lebih diminati terutama untuk

DOI: $10.52362 /$ jisicom.v5i1.466

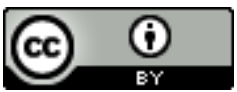

Ciptaan disebarluaskan di bawah Lisensi Creative Commons Atribusi 4.0 Internasional. 
Journal of Information System, Informatics and Computing

Website/URL: http://journal.stmikjayakarta.ac.id/index.php/jisicom

Email: jisicom@stmikjayakarta.ac.id , jisicom2017@gmail.com

perjalanan jauh, karena waktu tempuh akan relatif lebih singkat, ditambah keunggulan lainya seperti tersedianya pelayanan yang baik, pengoperasian yang diandalkan, kemampuan yang baik, serta frekuensi yang terjadwal [1].

Jumlah penumpang di Bandara Sukarno Hatta berdasarkan data statistik pada situs BPS (Badan Pusat statistic) pada tahun 2019 mencapai 19,3 juta penumpang [2], membuktikan bahwa minat masyarakat dalam menggunakan mode transportasi udara sangatlah tinggi.

PT. Jata Karunia Indonesia merupakan perusahaan yang bergerak dibidang tour dan travel. Pada tahun 2019, melakukan penjualan tiket sebanyak 4.687 tiket dengan omzet sebesar 32.7 milyar rupiah. Dengan jumlah penjualan yang cukup besar, staff ticketing dituntut unuk lebih cepat dan tepat dalam melayani konsumen, salah satunya adalah memberikan rekomendasi maskapai penerbangan yang baik kepada konsumen, agar konsumen puas, dimana kualitas pelayanan ini akan memberikan dampak positif, dalam melakukan pembelian tiket berikutnya. Pelayanan yang baik dapat dilihat dari cara memberikan informasi yang tepat tepat dan cepat serta lengkap dan terpercaya sesuai kebutuhan konsumen [3]. Pada penelitian sebelumnya bunawan tahun 2020, menerapkan metode TOPSIS dan Weighted Product dalam menentukan maskapai terbaik, dimana hasil yang diperoleh dengan menerapkan metode tersebut sama dan tidak terdapat perbedaan [4], pada penelitian kali ini, peneliti ingin menerapkan metode yang berbeda, yaitu dengan menerapkan metode Multi Factor Evaluation Process (MFEP).

Metode MFEP merupakan metode pengambilan keputusan dengan melibatkan beberapa faktor yang memiliki bobot sendiri, dimana nilai bobot dari faktor inilah yang akan dipakai sebagai perbandingan [5], metode dapat digunakan dalam menentukan kondisi bibit tanaman buncis, dari keutuhan, warna kulit serta bentuk biji buncis yang layak [6]. Keputusan yang berpengaruh secara strategis lebih dianjurkan untuk menggunakan sebuah pendekatan kuantitatif seperti Multifactor Evaluation Process [7], dimana alternatif tertinggi adalah solusi terbaik [8].

\section{METODE DAN MATERI}

\subsection{Metode Penelitian}

Penelitian ini merupakan pengembangan atau lanjutan dari penelitian sebelumnya dimana penelitian sebelumnya menerapkan metode TOPSIS dan Weighted Product [4]. Metode penelitian yang digunakan yaitu :

1. Identifikasi masalah : yaitu dengan mengidentifikasi masalah terkait dengan pemberian keputusan dalam merekomendasikan maskapai penerbangan.

2. Pengumpulan Data : yang dilakukan dengan cara, penyebaran kuesioner,wawancara dan studi Pustaka.

3. Analisa : yaitu dengan proses penganalisaan terhadap masalah yang ada pada penelitian ini, dengan menentukan faktor terpenting yang akan digunakan, yaitu : fasilitas, pelayanan dan kenyamanan, ketepatan waktu penerbangan, Refund, Riwayat Kecelakaan dan yang terakhir yaitu harga.

4. Penerapan Metode dengan menggunakan metode Multi Factor Evaluation Process (MFEP)

5. Kesimpulan, yaitu menarik kesimpulan berdasarkan hasil dari penelitian

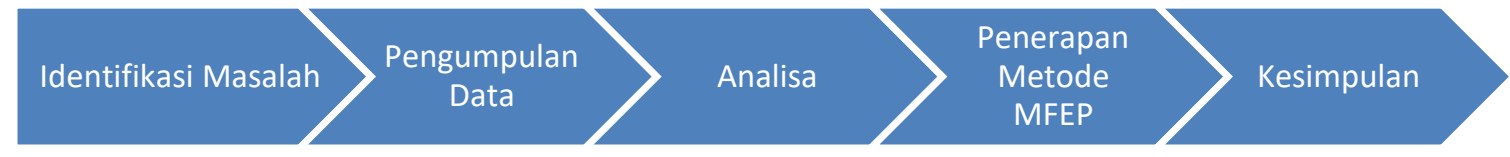

Gambar 1 Metode Penelitian

\subsection{Pengertian Keputusan}

Keputusan adalah proses menghasilkan pilihan terbaik dari beberapa alternatif dimulai dari pengumpulan data dan informasi serta menerapkan metode yang akan digunakan dengan mencurahkan segala pemikiran [9] .

\subsection{Proses Pengambilan Keputusan}

Proses dalam pengambilan keputusan dapat dijadikan sebagai suatu sistem [9], yang terdiri dari :

1. Masukan (input)

DOI: $10.52362 /$ jisicom.v5i1.466

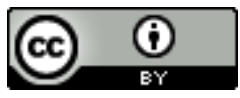

Ciptaan disebarluaskan di bawah Lisensi Creative Commons Atribusi 4.0 Internasional. 
Data dan informasi merupakan dua komponen dalam masukan masukan dalam pengambilan keputusan. Dimana data perlu diolah agar menghasilkan sebuah infrormasi yang dapat dijadikan masukan dalam pengambilan keputusan.

2. Proses

Langkah-langkah yang dilakukan dalam pengambilan keputusan dengan memikirkan secara detail mengenai keputusan yang diambilnya. Sistem pendukung keputusan disini memberikan dukungan bukan mengantikan pengambil keputusan.

3. Keluaran (Output)

Merupakan hasil dari proses pengambilan keputusan berupa informasi dari alternatif-alternatif terbaik dari beberapa alternatif yang ditawarkan.

\subsection{Multi Factor Evaluatin Process (MFEP)}

Metode Multi Factor Evaluation Process (MFEP), merupakan metode kuantitatif berbasis Weighting System, dimana keputusan yang bersifat strategis sangat disarankan menggunakan metode ini, karena seluruh kriteria yang merupakan faktor penting dalam pengambilan keputusan akan diberikan bobot yang sesuai [10]. Tahapan dalam menerapkan metode MFEP adalah :

1. Menentukan kriteria dari faktor yang dianggap penting dalam pengambilan keputusan

2. Memberikan nilai bobot untuk setiap faktor berdasarkan kepentingan nya, dimana nilai dari total pembobotan adalah 1

$\sum$ value weight factor $=1$

3. Mengisi nilai semua faktor berdasarkan data evaluasi

4. Melakukan proses perhitungan weight evaluation, yaitu proses proses perhitungan antara Bobot faktor (wight factor) dengan Evaluasi Faktor (evaluation factor), kemudian menjumlahkan seluruh hasil weight factor untuk mendapatkan total evaluasi.

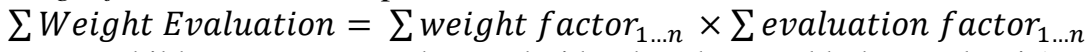

5. Mengambil keputusan atau rekomendasi berdasarkan total bobot evaluasi (total weight evaluation)

\section{PEMBAHASA DAN HASIL}

\subsection{Pembahasan}

Pada tahapan ini akan dilakukan proses perhitungan dengan menggunakan metode Multi Factor Evaluation Process pada penentuan Maskapai Terbaik pada PT. Jata Karunia Indonesia. Data diperolah dari hasil kuesioner yang disebarkan kepada para pelanggan PT. Jata Karunia Indonesia sebanyak 30 orang yang merupakan pengguna jasa transportasi pesawat terbang. Beberapa faktor yang digunakan dalam menentukan pemilihan maskapai terbaik adalah :

1. Fasilitas, Pelayanan dan Kenyamanan

Fasilitas, pelayanan dan kenyamanan merupakan faktor yang penting dalam pemilihan maskapai, fasilitasfasilitas yang lengkap dapat berbanding lurus terhadap pelayanan dan kenyamanan terhadap penumpang, begitu pula pelayanan dari kru pesawat saat di atas pesawat, maupun pelayanan frontline saat tidak berada di pesawat.

2. Ketepatan waktu penerbangan

Faktor utama yang biasanya dicari oleh penumpang maskapai yaitu waktu keberangkatan, apakah tepat atau sering delay, kecuali dikarenakan bencana alam atau cuaca yang tidak mendukung dilakukannya penerbangan

3. Refund

Refund merupakan pengembalian dana pembelian tiket yang tidak terpakai atau dibatalkan oleh penumpang. Proses pengembalian atau besaran dana yang kembali ke penumpang merupakan salah satu alasan yang dijadikan calon penumpang dalam memilih maskapai.

4. Riwayat Kecelakaan

DOI: $10.52362 /$ jisicom.v5i1.466

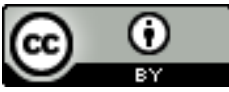

Ciptaan disebarluaskan di bawah Lisensi Creative Commons Atribusi 4.0 Internasional. 
Journal of Information System, Informatics and Computing

Website/URL: http://journal.stmikjayakarta.ac.id/index.php/jisicom

Email: jisicom@stmikjayakarta.ac.id , jisicom2017@gmail.com

Setiap maskapai mempunyai rekam jejak masing-masing, terutama riwayat kecelakaan, faktor keamanan dan kepercayaan terhadap maskapai akan terbentuk di masyarakat berdasarkan rekam jejak tersebut.

5. Harga

Harga yang ditawarkan maskapai menjadi salah satu faktor pelanggan dalam memilih maskapai, maskapai yang memberikan harga terjangkau dan lebih murah namun berkualitas, akan menjadi pilihan utama bagi calon penumpang

Sedangkan alternatif yang akan digunakan adalah data sepuluh (10) besar penjualan tiket terbanyak dalam rentang waktu tahun 2017 sampai dengan 2019:

1. Emirates

2. Ethiopian Airlines

3. Garuda Indonesia

4. Lion Airlines

5. Malaysia Airlines

6. Qantas Airways

7. Qatar Airways

8. Singapore Airlines

9. Thai Airways

10. Turkish Airlines

Berikut adalah bentuk kuesioner yang disebar kepada para responden, seperti terlihat pada tabel

Tabel 1 Kuesioner Penentuan Maskapai Terbaik

Fasilitas, pelayanan dan kenyamanan $($ F1)

F1.1 Kelengkapan fasilitas yang disediakan oleh maskapai sangat penting bagi saya dalam memilih maskapai yang akan saya gunakan

F1.2 Pelayanan yang baik yang diberikan oleh maskapai sangat penting bagi saya dalam memlih maskapai yang akan saya pilih

F1.3 Kenyamanan yang diberikan maskapai saat menunggu pesawat dan saat berada diatas pesawat sangat penting bagi saya sebagai kriteria dalam memilih maskapai

\section{Refund (F2)}

F2.1 Maskapai yang menjanjikan refund kembali jika tiket tidak digunakan merupakan prioritas bagi saya dalam memilih maskapai tersebut

F2.2 Maskapai yang menjanjikan refund kembali yang besar jika tiket tidak digunakan merupakan prioritas bagi saya dalam memilih maskapai tersebut

F3.3 Maskapai yang memberikan waktu pengembalian proses refund yang sebentar merupakan prioritas bagi saya dalam memilih maskapai tersebut

\section{Ketepatan waktu (F3)}

F3.1 Ketepatan waktu penerbangan yang diberikan maskapai merupakan hal penting bagi saya dalam memilih maskapai tersebut

F3.2 Maskapai dengan reputasi baik dalam hal ketepatan waktu penerbangan merupakan prioritas bagi anda dalam memilih maskapai tersebut

DOI: $10.52362 /$ jisicom.v5i1.466

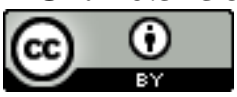

Ciptaan disebarluaskan di bawah Lisensi Creative Commons Atribusi 4.0 Internasional. 
Journal of Information System, Informatics and Computing

Website/URL: http://journal.stmikjayakarta.ac.id/index.php/iisicom

Email: jisicom@stmikjayakarta.ac.id , jisicom2017@gmail.com

F3.3 Maskapai yang mempunyai reputasi lebih baik saat terpaksa delay merupakan priorotas bagi anda dalam memilih maskapai tersebut

\section{Riwayat kecelakaan (F4)}

F4.1 Daftar riwayat kecelakaan sebuah maskapai sangat penting bagi saya dalam menentukan maskapai tersebut saya pilih atau tidak

F4.2 Maskapai yang jarang bahkan tidak pernah mengalami kecelakaan merupakan prioritas bagi anda dalam memilih maskapai tersebut.

F4.3 Maskapai yang mempunya reputasi baik perihal penanganan kecelakaan akan membuat anda lebih memilih maskapai tersebut.

\section{Harga (F5)}

F5.1

Harga yang maskapai tawarkan kepada pengguna merupakan salah satu alasan saya dalam memilih maskapai.

F5.2 Saya memilih maskapai berlatar belakang harga yang diberikan

F5.3 Maskapai yang mempunyai reputasi sebagai maskapai yang berharga ekonomis menjadikan saya memilih maskapai tersebut.

Dari kuesioner yang disebarkan kepada para responden, maka dapat dilakukan perhitungan pencarian nilai bobot setiap faktor nya. Berikut Perhitungan pencarian nilai bobot tiap kriteria:

$$
\begin{aligned}
& \text { Nilai Bobot } F 1=\frac{402}{(402+302+362+310+309)}=\frac{402}{1685}=0.239 \\
& \text { Nilai Bobot } F 2=\frac{302}{(402+302+362+310+309)}=\frac{362}{1685}=0.179 \\
& \text { Nilai Bobot } F 3=\frac{362}{(402+302+362+310+309)}=\frac{310}{1685}=0.215 \\
& \text { Nilai Bobot } F 4=\frac{310}{(402+302+362+310+309)}=0.184 \\
& \text { Nilai Bobot } F 5=\frac{309}{(402+302+362+310+309)}=\frac{309}{1685}=0.183
\end{aligned}
$$

Dari data-data tersebut, maka kita dapat melanjutkan proses perhitungan Multi Factor Evaluation Process (MFEP) dengan Langkah-langkah sebagai berikut :

1. Menentukan faktor dan bobot dimana total pembobotan adalah sebesar 1, dapat dilihat pada tabel 2.

Tabel 2 Faktor dan Nilai Bobot Faktor

\begin{tabular}{clc}
\hline Kriteria & \multicolumn{1}{c}{ Faktor } & Nilai Bobot Faktor \\
\hline F1 & Fasilitas, pelayanan dan kenyamanan & 0.239 \\
F2 & Refund & 0.179 \\
F3 & Ketepatan waktu & 0.215 \\
F4 & Riwayat kecelakaan & 0.184 \\
F5 & Harga & 0.183 \\
\hline
\end{tabular}

DOI: $10.52362 /$ jisicom.v5i1.466

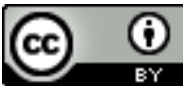

Ciptaan disebarluaskan di bawah Lisensi Creative Commons Atribusi 4.0 Internasional. 
e-ISSN : 2597-3673 (Online) , p-ISSN : 2579-5201 (Printed)

Vol.5 No.1, Juni 2021

Journal of Information System, Informatics and Computing

Website/URL: http://journal.stmikjayakarta.ac.id/index.php/jisicom

Email: jisicom@stmikjayakarta.ac.id, jisicom2017@gmail.com

Jumlah Bobot Faktor

1

2. Mengisi nilai untuk setiap faktor yang telah ditentukan yang mempengaruhi dalam pengambilan keputusan. Nilai yang akan dimasukan adalah 1 sampai dengan 5 dengan ketentuan sebagai berikut :

Tabel 3 Ketentuan Penilaian

\begin{tabular}{ccc}
\hline Penilaian & \multicolumn{2}{c}{ Klasifikasi Kriteria } \\
\cline { 2 - 3 } & Benefit & Cost \\
\hline Sangat Baik & 5 & 2 \\
Baik & 4 & 3 \\
Sedang & 3 & 4 \\
Buruk & 2 & 5 \\
\hline
\end{tabular}

Dari tabel diatas yang menjadi dasar penilaian, maka dapat dimasukan ke dalam setiap alternatif, seperti pada tabel dibawah ini.

Tabel 4 Data Nilai Evaluasi Faktor

\begin{tabular}{lrrrrrrrrrr}
\hline \multicolumn{1}{c}{ Faktor } & A1 & A2 & A3 & A4 & A5 & A6 & A7 & A8 & A9 & A10 \\
\hline Fasilitas, pelayanan dan kenyamanan & 5 & 4 & 5 & 3 & 4 & 4 & 5 & 5 & 4 & 4 \\
Refund & 4 & 3 & 5 & 3 & 4 & 3 & 5 & 4 & 4 & 3 \\
Ketepatan waktu & 5 & 3 & 5 & 3 & 4 & 4 & 4 & 4 & 4 & 3 \\
Riwayat kecelakaan & 1 & 2 & 1 & 3 & 2 & 2 & 2 & 2 & 2 & 2 \\
Harga & 5 & 4 & 5 & 3 & 4 & 4 & 4 & 4 & 5 & 5 \\
\hline
\end{tabular}

3. Melakukan proses perhitungan weight evaluation, yaitu proses proses perhitungan antara Bobot faktor dengan Evaluasi Faktor, kemudian menjumlahkan seluruh hasil weight factor untuk mendapatkan total evaluasi. Hasil tersebut dapat dilihat pada tabel dibawah ini.

Tabel 5 Perhitungan Untuk Mendapatkan Bobot Evaluasi Alternatif 1

\begin{tabular}{|c|c|c|c|c|c|}
\hline Faktor & $\begin{array}{l}\text { Bobot } \\
\text { Faktor } \\
\end{array}$ & & $\begin{array}{l}\text { Evaluasi } \\
\text { Faktor } \\
\end{array}$ & & $\begin{array}{l}\text { Bobot } \\
\text { Evaluasi }\end{array}$ \\
\hline Fasilitas, pelayanan dan kenyamanan & 0.239 & $\mathrm{x}$ & 5 & $=$ & 1.195 \\
\hline Refund & 0.179 & $\mathrm{x}$ & 4 & $=$ & 0.716 \\
\hline Ketepatan waktu & 0.215 & $\mathrm{x}$ & 5 & $=$ & 1.075 \\
\hline Riwayat kecelakaan & 0.184 & $\mathrm{x}$ & 1 & $=$ & 0.184 \\
\hline Harga & 0.183 & $\mathrm{x}$ & 5 & $=$ & 0.915 \\
\hline Total & \multicolumn{3}{|c|}{1} & & 4.085 \\
\hline
\end{tabular}

Pada tabel 5, hasil total bobot Evaluasi untuk alternatif 1 adalah sebesar 4.085

Tabel 6 Perhitungan Untuk Mendapatkan Bobot Evaluasi Alternatif 2

\begin{tabular}{|c|c|c|c|c|c|}
\hline Faktor & $\begin{array}{l}\text { Bobot } \\
\text { Faktor }\end{array}$ & & $\begin{array}{l}\text { Evaluasi } \\
\text { Faktor }\end{array}$ & & $\begin{array}{l}\text { Bobot } \\
\text { Evaluasi }\end{array}$ \\
\hline Fasilitas, pelayanan dan kenyamanan & 0.239 & X & 4 & $=$ & 0.956 \\
\hline Refund & 0.179 & 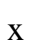 & 3 & $=$ & 0.537 \\
\hline
\end{tabular}

DOI: $10.52362 /$ jisicom.v5i1.466

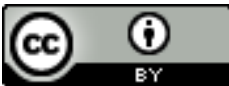

Ciptaan disebarluaskan di bawah Lisensi Creative Commons Atribusi 4.0 Internasional. 
e-ISSN : 2597-3673 (Online) , p-ISSN : 2579-5201 (Printed)

Vol.5 No.1, Juni 2021

Journal of Information System, Informatics and Computing

Website/URL: http://journal.stmikjayakarta.ac.id/index.php/jisicom

Email: jisicom@stmikjayakarta.ac.id , jisicom2017@gmail.com

\begin{tabular}{|c|c|c|c|c|c|}
\hline Ketepatan waktu & 0.215 & $\mathrm{x}$ & 3 & $=$ & 0.645 \\
\hline Riwayat kecelakaan & 0.184 & $\mathrm{x}$ & 2 & $=$ & 0.368 \\
\hline Harga & 0.183 & $\mathrm{x}$ & 4 & $=$ & 0.732 \\
\hline Total & 1 & & & & 3.238 \\
\hline
\end{tabular}

Pada tabel 6, hasil total bobot Evaluasi untuk alternatif 2 adalah sebesar 3.238

Tabel 7 Perhitungan Untuk Mendapatkan Bobot Evaluasi Alternatif 3

\begin{tabular}{|c|c|c|c|c|c|}
\hline Faktor & $\begin{array}{l}\text { Bobot } \\
\text { Faktor } \\
\end{array}$ & & $\begin{array}{l}\text { Evaluasi } \\
\text { Faktor }\end{array}$ & & $\begin{array}{l}\text { Bobot } \\
\text { Evaluasi }\end{array}$ \\
\hline Fasilitas, pelayanan dan kenyamanan & 0.239 & $\mathrm{x}$ & 5 & $=$ & 1.195 \\
\hline Refund & 0.179 & $\mathrm{x}$ & 5 & $=$ & 0.895 \\
\hline Ketepatan waktu & 0.215 & $\mathrm{x}$ & 5 & $=$ & 1.075 \\
\hline Riwayat kecelakaan & 0.184 & $\mathrm{x}$ & 1 & $=$ & 0.184 \\
\hline Harga & 0.183 & $\mathrm{x}$ & 5 & $=$ & 0.915 \\
\hline Total & \multicolumn{3}{|c|}{1} & & 4.264 \\
\hline
\end{tabular}

Pada tabel 7, hasil total bobot Evaluasi untuk alternatif 3 adalah sebesar 4.264

Tabel 8 Perhitungan Untuk Mendapatkan Bobot Evaluasi Alternatif 4

\begin{tabular}{|c|c|c|c|c|c|}
\hline Faktor & $\begin{array}{l}\text { Bobot } \\
\text { Faktor } \\
\end{array}$ & & $\begin{array}{l}\text { Evaluasi } \\
\text { Faktor }\end{array}$ & & $\begin{array}{l}\text { Bobot } \\
\text { Evaluasi }\end{array}$ \\
\hline Fasilitas, pelayanan dan kenyamanan & 0.239 & $\mathrm{x}$ & 3 & $=$ & 0.717 \\
\hline Refund & 0.179 & $\mathrm{x}$ & 3 & $=$ & 0.537 \\
\hline Ketepatan waktu & 0.215 & $\mathrm{x}$ & 3 & $=$ & 0.645 \\
\hline Riwayat kecelakaan & 0.184 & $\mathrm{x}$ & 3 & $=$ & 0.552 \\
\hline Harga & 0.183 & $\mathrm{x}$ & 3 & $=$ & 0.549 \\
\hline Total & \multicolumn{3}{|l|}{1} & & 3 \\
\hline
\end{tabular}

Pada tabel 8, hasil total bobot Evaluasi untuk alternatif 4 adalah sebesar 3

Tabel 9 Perhitungan Untuk Mendapatkan Bobot Evaluasi Alternatif 5

\begin{tabular}{|c|c|c|c|c|c|}
\hline Faktor & $\begin{array}{l}\text { Bobot } \\
\text { Faktor }\end{array}$ & & $\begin{array}{l}\text { Evaluasi } \\
\text { Faktor }\end{array}$ & & $\begin{array}{l}\text { Bobot } \\
\text { Evaluasi }\end{array}$ \\
\hline Fasilitas, pelayanan dan kenyamanan & 0.239 & $\mathrm{x}$ & 4 & $=$ & 0.956 \\
\hline Refund & 0.179 & $\mathrm{x}$ & 4 & $=$ & 0.716 \\
\hline Ketepatan waktu & 0.215 & $\mathrm{x}$ & 4 & $=$ & 0.86 \\
\hline Riwayat kecelakaan & 0.184 & $\mathrm{x}$ & 2 & $=$ & 0.368 \\
\hline Harga & 0.183 & $\mathrm{x}$ & 4 & $=$ & 0.732 \\
\hline Total & \multicolumn{3}{|c|}{1} & & 3.632 \\
\hline
\end{tabular}

Pada tabel 9, hasil total bobot Evaluasi untuk alternatif 5 adalah sebesar 3.632

Tabel 10 Perhitungan Untuk Mendapatkan Bobot Evaluasi Alternatif 6

\begin{tabular}{|c|c|c|c|}
\hline Faktor & $\begin{array}{l}\text { Bobot } \\
\text { Faktor }\end{array}$ & $\begin{array}{l}\text { Evaluasi } \\
\text { Faktor }\end{array}$ & $\begin{array}{l}\text { Bobot } \\
\text { Evaluasi }\end{array}$ \\
\hline Fasilitas, pelayanan dan kenyamanan & 0.239 & 4 & 0.956 \\
\hline
\end{tabular}

DOI: $10.52362 /$ jisicom.v5i1.466

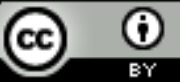

Ciptaan disebarluaskan di bawah Lisensi Creative Commons Atribusi 4.0 Internasional. 
e-ISSN : 2597-3673 (Online) , p-ISSN : 2579-5201 (Printed)

Vol.5 No.1, Juni 2021

Journal of Information System, Informatics and Computing

Website/URL: http://journal.stmikjayakarta.ac.id/index.php/jisicom

Email: jisicom@stmikjayakarta.ac.id , jisicom2017@gmail.com

\begin{tabular}{|c|c|c|c|c|c|}
\hline Refund & 0.179 & $\mathrm{x}$ & 3 & $=$ & 0.537 \\
\hline Ketepatan waktu & 0.215 & $\mathrm{x}$ & 4 & $=$ & 0.86 \\
\hline Riwayat kecelakaan & 0.184 & $\mathrm{x}$ & 2 & $=$ & 0.368 \\
\hline Harga & 0.183 & $\mathrm{x}$ & 5 & $=$ & 0.915 \\
\hline Total & 1 & & & & 3.636 \\
\hline
\end{tabular}

Pada tabel 10, hasil total bobot Evaluasi untuk alternatif 6 adalah sebesar 3.636

Tabel 11 Perhitungan Untuk Mendapatkan Bobot Evaluasi Alternatif 7

\begin{tabular}{|c|c|c|c|c|c|}
\hline Faktor & $\begin{array}{l}\text { Bobot } \\
\text { Faktor } \\
\end{array}$ & & $\begin{array}{l}\text { Evaluasi } \\
\text { Faktor } \\
\end{array}$ & & $\begin{array}{l}\text { Bobot } \\
\text { Evaluasi }\end{array}$ \\
\hline Fasilitas, pelayanan dan kenyamanan & 0.239 & $\mathrm{x}$ & 5 & $=$ & 1.195 \\
\hline Refund & 0.179 & $\mathrm{x}$ & 5 & $=$ & 0.895 \\
\hline Ketepatan waktu & 0.215 & $\mathrm{x}$ & 4 & $=$ & 0.86 \\
\hline Riwayat kecelakaan & 0.184 & $\mathrm{x}$ & 2 & $=$ & 0.368 \\
\hline Harga & 0.183 & $\mathrm{x}$ & 4 & $=$ & 0.732 \\
\hline Total & \multicolumn{3}{|c|}{1} & & 4.05 \\
\hline
\end{tabular}

Pada tabel 11, hasil total bobot Evaluasi untuk alternatif 7 adalah sebesar 4.05

Tabel 12 Perhitungan Untuk Mendapatkan Bobot Evaluasi Alternatif 8

\begin{tabular}{|c|c|c|c|c|c|}
\hline Faktor & $\begin{array}{l}\text { Bobot } \\
\text { Faktor } \\
\end{array}$ & & $\begin{array}{l}\text { Evaluasi } \\
\text { Faktor }\end{array}$ & & $\begin{array}{l}\text { Bobot } \\
\text { Evaluasi }\end{array}$ \\
\hline Fasilitas, pelayanan dan kenyamanan & 0.239 & $\mathrm{x}$ & 5 & $=$ & 1.195 \\
\hline Refund & 0.179 & $\mathrm{x}$ & 4 & $=$ & 0.716 \\
\hline Ketepatan waktu & 0.215 & $\mathrm{x}$ & 4 & $=$ & 0.86 \\
\hline Riwayat kecelakaan & 0.184 & $\mathrm{x}$ & 2 & $=$ & 0.368 \\
\hline Harga & 0.183 & $\mathrm{x}$ & 4 & $=$ & 0.732 \\
\hline Total & \multicolumn{3}{|l|}{1} & & 3.871 \\
\hline
\end{tabular}

Pada tabel 12, hasil total bobot Evaluasi untuk alternatif 8 adalah sebesar 3.871

Tabel 13 Perhitungan Untuk Mendapatkan Bobot Evaluasi Alternatif 9

\begin{tabular}{|c|c|c|c|c|c|}
\hline Faktor & $\begin{array}{l}\text { Bobot } \\
\text { Faktor }\end{array}$ & & $\begin{array}{l}\text { Evaluasi } \\
\text { Faktor }\end{array}$ & & $\begin{array}{l}\text { Bobot } \\
\text { Evaluasi }\end{array}$ \\
\hline Fasilitas, pelayanan dan kenyamanan & 0.239 & $\mathrm{x}$ & 4 & $=$ & 0.956 \\
\hline Refund & 0.179 & $\mathrm{x}$ & 4 & $=$ & 0.716 \\
\hline Ketepatan waktu & 0.215 & $\mathrm{x}$ & 4 & $=$ & 0.86 \\
\hline Riwayat kecelakaan & 0.184 & $\mathrm{x}$ & 2 & $=$ & 0.368 \\
\hline Harga & 0.183 & $\mathrm{X}$ & 5 & $=$ & 0.915 \\
\hline Total & 1 & & & & 3.815 \\
\hline
\end{tabular}

Pada tabel 13 hasil total bobot Evaluasi untuk alternatif 9 adalah sebesar 3.815

DOI: $10.52362 /$ jisicom.v5i1.466

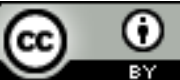

Ciptaan disebarluaskan di bawah Lisensi Creative Commons Atribusi 4.0 Internasional. 
Journal of Information System, Informatics and Computing

Website/URL: http://journal.stmikjayakarta.ac.id/index.php/jisicom

Email: jisicom@stmikjayakarta.ac.id , jisicom2017@gmail.com

Tabel 14 Perhitungan Untuk Mendapatkan Bobot Evaluasi Alternatif 10

\begin{tabular}{|c|c|c|c|c|c|}
\hline Faktor & $\begin{array}{l}\text { Bobot } \\
\text { Faktor } \\
\end{array}$ & & $\begin{array}{l}\text { Evaluasi } \\
\text { Faktor }\end{array}$ & & $\begin{array}{l}\text { Bobot } \\
\text { Evaluasi }\end{array}$ \\
\hline Fasilitas, pelayanan dan kenyamanan & 0.239 & $\mathrm{x}$ & 4 & $=$ & 0.956 \\
\hline Refund & 0.179 & $\mathrm{x}$ & 3 & $=$ & 0.537 \\
\hline Ketepatan waktu & 0.215 & $\mathrm{x}$ & 3 & $=$ & 0.645 \\
\hline Riwayat kecelakaan & 0.184 & $\mathrm{x}$ & 2 & $=$ & 0.368 \\
\hline Harga & 0.183 & $\mathrm{x}$ & 5 & $=$ & 0.915 \\
\hline Total & \multicolumn{3}{|c|}{1} & & 3.421 \\
\hline
\end{tabular}

Pada tabel 14, hasil total bobot Evaluasi untuk alternatif 10 adalah sebesar 3.42

3.2. Hasil

Dari perhitungan total bobot Evaluasi, yang diperoleh dari penjumlahan bobot evaluasi setiap faktor pada setiap alternatifnya, maka didapatlah hasil akhir seperti yang terlihat pada tabel dibawah ini.

Tabel 15 Jumlah Hasil Perhitungan

\begin{tabular}{ccc}
\hline Alternatif & Jumlah Nilai & Ranking \\
\hline A1 & 4.085 & 2 \\
A2 & 3.238 & 9 \\
A3 & 4.264 & 1 \\
A4 & 3 & 10 \\
A5 & 3.632 & 7 \\
A6 & 3.636 & 6 \\
A7 & 4.05 & 3 \\
A8 & 3.871 & 4 \\
A9 & 3.815 & 5 \\
A10 & 3.421 & 8 \\
\hline
\end{tabular}

Dari tabel penjumlahan bobot dan faktor, maka hasil tertinggi yang akan direkomendasikan menjadi maskapai terbaik adalah alternatif 3, yaitu Garuda Indonesia dimana fasilitas, pelayanan dan kenyaman mendapatkan weight evaluation sebesar 1.195 dan mempunyai Riwayat kecelakaan sangat kecil yaitu sebesar 0.184, sedangkan urutan terakhir yang akan direkomendasikan adalah alternatif 4, yaitu Lion Airlines dimana nilai fasilitas, pelayanan dan kenyaman adalah sebesar 0.717 dan mempunyai Riwayat kecelakaan yang sangat besar yaitu sebesar 0.552 .

\section{KESIMPULAN}

Berdasakan hasil penelitian, maka dapat diambil beberapa kesimpulan yaitu:

1. Pada hasil perhitungan dengan menggunakan metode Multi Factor Evaluation Process, maka 3 (tiga) maskapai terbaik yang akan direkomendasikan yaitu Garuda Indonesia dengan nilai sebesar 4.264, pada urutan kedua yaitu Emirates dengan nilai sebesar 4.085, dan urutan ketiga yaitu Qantas Airways dengan nilai sebesar 4.05 .

DOI: $10.52362 /$ jisicom.v5i1.466

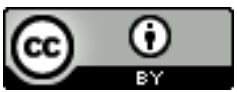

Ciptaan disebarluaskan di bawah Lisensi Creative Commons Atribusi 4.0 Internasional. 
2. Sedangkan 3 (tiga) posisi terakhir yang akan direkomendasikan adalah Turkish Airlines dengan nilai 3.421, selanjutnya Ethiopian Airline dengan nilai 3.238 dan posisi terakhir ditempati oleh maskapai Lion Air dengan nilai 3, ini disebabkan karena maskapai Lion Air mempunyai bobot evaluasi sebesar 0.552, yang berarti disebabkan oleh faktor Riwayat kecelakaan yang cukup besar.

Diharapkan pada penelitian selanjutnya dapat menggunakan metode lain dan menambah faktor- faktor agar hasil penelitian selanjutnya dapat lebih baik.

\section{REFERENASI}

[1] F. Z. Hidayat and P. L. Samputra, "Evaluasi tingkat kepuasan masyarakat pengguna maskapai penerbangan kelas ekonomi sebelum dan setelah kebijakan kenaikan tarif tiket," Akuntabel, vol. 17, no. 14, pp. 122-132, 2020.

[2] Badan Pusat Statistik, "Jumlah Penumpang yang Berangkat pada Penerbangan Domestik di Bandara Utama Indonesia, 2006-2020," 2020. .

[3] P. P. Susansti, I. N. Sudiarta, and I. M. K. Negara, “Analisis Tingkat Kepuasan Wisatawan Terhadap Kualitas Pelayanan Di MBA Tour \& Travel,” J. IPTA, vol. 4, no. 1, pp. 86-90, 2016.

[4] A. Bunawan, "Komparasi Metode TOPSIS dan Weighted Product Dalam Menentukan Maskapai Terbaik Pada PT. Jata Karunia Indonesia,” Nusa Mandiri, 2020.

[5] R. Hadi, "Penerapan Metode Multifactor Evaluation Process Untuk Pemilihan Supplier Kertas Pada Percetakan," Pros. SINTAK, vol. 2, no. 2, pp. 233-238, 2018, [Online]. Available: https://www.unisbank.ac.id/ojs/index.php/sintak/article/view/6594.

[6] M. H. Ramadhan and Yusfrizal, “Analisis Dan Penerapan Metode Multifactor Evaluation Process (MFEP) Dalam Menentukan Bibit Tanaman Buncis Yang Layak Untuk Dibudidayakan,” J. Sist. Inf. Kaputama, vol. 3, no. 1, pp. 18-26, 2019, [Online]. Available: https://jurnal.kaputama.ac.id/index.php/JSIK/article/view/148/pdf.

[7] H. Bastiawati and D. Setiyadi, "Seleksi Calon Koordinator Marketing Provinsi dengan Metode Multifactor Evaluation Process,” J. Informatics Educ. Prof., vol. 2, no. 1, pp. 81-94, 2017, [Online]. Available: https://media.neliti.com/media/publications/234406-seleksi-calon-koordinator-marketing-prov-7445bc29.pdf.

[8] R. Turaina, N. E. Putri, and R. Rizki, "SPK Dalam Pemilihan Siswa Kelas Unggul Menggunakan Metode MFEP Di SMP N 2 Solok,” Edik Inform., vol. 3, no. 2, pp. 125-135, 2017, doi: 10.22202/ei.2017.v3i2.1662.

[9] Diana, Metode \& Aplikasi Sistem Pendukung Keputusan. Yogyakarta: Deepublish, 2018.

[10] H. Pratiwi, Buku Ajar Sistem Pendukung Keputusan, 1st ed. Yogyakarta: Deepublish, 2016.

DOI: $10.52362 /$ jisicom.v5i1.466

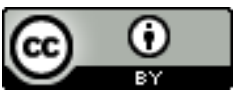

Ciptaan disebarluaskan di bawah Lisensi Creative Commons Atribusi 4.0 Internasional. 